\title{
Estimation of soil redistribution rates due to snow cover related processes in a mountainous area (Valle d'Aosta, NW Italy)
}

\author{
E. Ceaglio $^{1,2,3}$, K. Meusburger ${ }^{4}$, M. Freppaz ${ }^{1}$, E. Zanini ${ }^{1}$, and C. Alewell ${ }^{4}$ \\ ${ }^{1}$ Dipartimento di Valorizzazione e Protezione delle Risorse Agroforestali - DIVAPRA, Chimica Agraria e Pedologia, LNSA \\ and NatRisk, University of Torino - Via Leonardo Da Vinci 44, 10095 Grugliasco (TO), Italy \\ ${ }^{2}$ Ufficio neve e valanghe, Direzione assetto idrogeologico dei bacini montani, Regione Autonoma Valle d'Aosta, \\ Loc. Amérique 44, 11020 Quart (AO), Italy \\ ${ }^{3}$ Fondazione Montagna Sicura - Montagne Sûre, Villa Cameron, Località Villard de la Palud 1, 11013 Courmayeur (AO), Italy \\ ${ }^{4}$ Institute of Environmental Geosciences, University of Basel, Bernoullistr. 30, 4056 Basel, Switzerland
}

Correspondence to: E. Ceaglio (eceaglio@fondms.org)

Received: 26 August 2011 - Published in Hydrol. Earth Syst. Sci. Discuss.: 21 September 2011

Revised: 27 January 2012 - Accepted: 1 February 2012 - Published: 17 February 2012

\begin{abstract}
Mountain areas are widely affected by soil erosion, which is generally linked to runoff processes occurring in the growing season and snowmelt period. Also processes like snow gliding and full-depth snow avalanches may be important factors that can enhance soil erosion, however the role and importance of snow movements as agents of soil redistribution are not well understood yet. The aim of this study was to provide information on the relative importance of snow related processes in comparison to runoff processes. In the study area, which is an avalanche path characterized by intense snow movements, soil redistribution rates were quantified with two methods: (i) by field measurements of sediment yield in an avalanche deposition area during 2009 and 2010 winter seasons; (ii) by caesium-137 method, which supplies the cumulative net soil loss/gain since 1986, including all the soil erosion processes. The snow related soil accumulation estimated with data from the deposit area (27.5 Mg ha ${ }^{-1}$ event $^{-1}$ and $161.0 \mathrm{Mg} \mathrm{ha}^{-1}$ event $^{-1}$ ) was not only higher than the yearly sediment amounts, reported in literature, due to runoff processes, but it was even more intense than the yearly total deposition rate assessed with ${ }^{137} \mathrm{Cs}\left(12.6 \mathrm{Mg} \mathrm{ha}^{-1} \mathrm{yr}^{-1}\right)$. The snow related soil erosion rates estimated from the sediment yield at the avalanche deposit area $\left(3.7 \mathrm{Mg} \mathrm{ha}^{-1}\right.$ and $20.8 \mathrm{Mg} \mathrm{ha}^{-1}$ ) were greater than the erosion rates reported in literature and related to runoff processes; they were comparable to the yearly total erosion rates assessed with the ${ }^{137} \mathrm{Cs}$ method $\left(13.4 \mathrm{Mg} \mathrm{ha}^{-1} \mathrm{yr}^{-1}\right.$ and $8.8 \mathrm{Mg} \mathrm{ha}^{-1} \mathrm{yr}^{-1}$ ). The ${ }^{137} \mathrm{Cs}$ method also showed that, where the ground avalanche does not release, the erosion and deposition of soil particles from the upper part of the basin was considerable and likely related to snow gliding. Even
\end{abstract}

though the comparison of both the approaches is linked to high methodological uncertainties, mainly due to the different spatial and temporal scales considered, we still can deduce, from the similarity of the erosion rates, that soil redistribution in this catchment is driven by snow movement, with a greater impact in comparison to the runoff processes occurring in the snow-free season. Nonetheless, the study highlights that soil erosion processes due to the snow movements should be considered in the assessment of soil vulnerability in mountain areas, as they significantly determine the pattern of soil redistribution.

\section{Introduction}

Soils in mountain areas are fragile and often scarcely developed, mainly because of slope steepness and extreme climate conditions, and they are widely affected by erosion processes and soil slip involving mainly superficial horizons. Main drivers for soil erosion are topography, land cover, soil texture, rainfall patterns and land use (Wischmeier and Smith, 1978). Soil erosion is mainly linked to rainfall runoff processes, but, in mountain areas, also snowmelt runoff and snow movement related processes may be important factors that can enhance soil erosion (Konz et al., 2009). The snow movements which could involve the soil are: (a) the snow gliding (slow glide movement of the snow cover on smooth or wet ground, that can lead to the formation of glide cracks), and (b) the ground avalanches (in particular the fulldepth slab avalanches or so called gliding avalanches, occurring when the snow gliding changes to a rapid movement) 
(www.avalanches.org). Also the snowmelt period can contribute significantly to the total annual runoff and sediment yield, constituted mainly by fine particles $(<2 \mathrm{~mm})$ (LanaRenault et al., 2011). However, the role and importance of snow movements as a soil erosion agent are not well understood yet. In fact, they can exert considerable erosive forces on soils; in particular avalanches can transport consistent amounts of debris, especially when they involve the whole depth of snow or run onto snow-free areas (Luckman, 1978; Freppaz et al., 2006, 2010; Confortola et al., 2011). The rock and soil material, transported by snow movements, origins from the erosion of the underlying soil and bedrock in the release zone and along the track area (Gardner, 1983; Jomelli and Bertran, 2001). Deposits of debris from snow avalanches are common in mountain environments indicating the importance of avalanches as specific geomorphic agents. Mapping and quantification of soil erosion under different land-use conditions have been evaluated in many projects for agricultural soils in lowlands. However, only few studies exist on soil erosion measurement and quantification in lowmountain ranges (e.g. Nearing et al., 1999; Leser et al., 2002; Gabriels et al., 2003; Prasuhn et al., 2007) or in alpine environments characterized by specific climatic and topographic conditions (Felix and Johannes, 1995; Descroix and Mathys, 2003; Isselin-Nondedeu and Bedecarrats, 2007; Konz et al., 2009, 2010, 2011; Meusburger et al., 2010). Moreover, most of the studies focus on soil erosion measurement during the vegetation period, while only few works deal with soil erosion caused by snow movements related processes (Ackroyd, 1987; Bell et al., 1990; Kohl et al., 2001; Heckmann et al., 2005; Konz et al., 2009, 2011; Freppaz et al,, 2010). Hence, more data on soil erosion in alpine regions, for longer time periods and including all the seasons, are needed (Konz et al., 2009). Taking into account the soil redistribution process related to the "snowy season", conventionally, it can be assessed by the measurement of sediments transported in the runout zones by snow movements (snow gliding and ground avalanches), considering both the debris and the fine material (e.g. Ackroyd, 1987; Bell et al., 1990; Kohl et al., 2001; Heckmann et al., 2005; Freppaz et al., 2010). On the other side the yearly soil erosion in mountain areas can be measured by isotopic techniques based on the use of fallout radionuclides "FRNs" such as ${ }^{137} \mathrm{Cs},{ }^{7} \mathrm{Be}$ and ${ }^{210} \mathrm{~Pb}$ (Zapata, 2002; Mabit et al., 2008a). "FRNs", in particular ${ }^{137} \mathrm{Cs}$, have proven to be very powerful tracers of soil movements within the landscape, and this methodology can complement conventional approaches (Mabit and Fulajtar, 2007). The presence of ${ }^{137} \mathrm{Cs}$ in the soil is either due to nuclear weapon testing (1960s) and/or to the Chernobyl reactor accident in 1986. Input of ${ }^{137} \mathrm{Cs}$ through the Chernobyl reactor accident was highly dependent on the rainfall pattern which caused high (kilometre to regional scale) heterogeneity in ${ }^{137} \mathrm{Cs}$ distribution (Higgitt et al., 1992; Renaud et al., 2003). For a small catchment or single hill slopes a homogeneous rainfall pattern can be assumed. After deposition, ${ }^{137} \mathrm{Cs}$ is rapidly and tightly bound to fine soil particles and its redistribution is mainly caused by soil erosion as it moves with soil particles (e.g. Bonnett, 1990; Ritchie and McHenry, 1990). The use of ${ }^{137} \mathrm{Cs}$ measurements to estimate rates of erosion and deposition is based on comparison of the inventories at individual sampling points with a reference inventory, representing the local fallout input. The reference site is expected to show neither erosion nor deposition. A measured inventory for an individual sampling point less than the reference value is indicative of erosion, whereas an inventory greater than reference value is indicative of deposition (Walling and He, 1999). To convert ${ }^{137} \mathrm{Cs}$ measurements to quantitative estimates of erosion and deposition rates, many different methods exist, including both empirical relationships, and theoretical models and accounting procedures (Walling and $\mathrm{He}, 1999$ ).

The aim of this study was to quantify soil erosion and deposition rates due to snow movements related processes (snow gliding and ground avalanches) by conventional field measurements in a snow deposition area. Moreover the yearly soil redistribution rates in different sites of the study area were assessed with the ${ }^{137} \mathrm{Cs}$-method, which yields the cumulative net soil loss/gain since 1986, including all the erosion processes. Our hypothesis was that the combination of the two approaches could provide information on the relative importance of soil erosion related to snow movements in comparison to runoff processes.

\section{Materials and methods}

\subsection{Study area}

The watershed investigated (24.6 ha) is located in the northwestern part of the Valle d'Aosta Region (NW-Italy), very close to the Mont Blanc Massif (4810 ma.s.l.) in the municipality of Courmayeur. The study area is an avalanche site called "Torrent des Marais", running on a west exposed slope, from $2115 \mathrm{~m}$ to $1250 \mathrm{~m}$ a.s.l. (Fig. 1). In this site, besides the dry snow avalanches, also wet snow, full-depth slab avalanches (gliding avalanches) occur, and they are typical during the spring time, and sometimes also in late autumn. The release and track areas are often characterized by intense snow gliding and glide cracks formation. All these processes are related to soil erosion. Full-depth slab avalanches often involve the soil surface with the removal, subsequent transport and accumulation in the deposition areas, of the upper horizons mixed with rocks and plant material. According to the Avalanche Cadastre of the Valle d'Aosta Region, in the last four years the frequency of gliding avalanches in the investigated area seemed to have increased: for each of the last four winters we had one documented event, while previous data recorded in the Regional Avalanche Cadastre, within the last four decades, indicate only few ground, wet snow avalanches. The last events took place during winter seasons with differing snow conditions (2007/2008: low snowfall; 


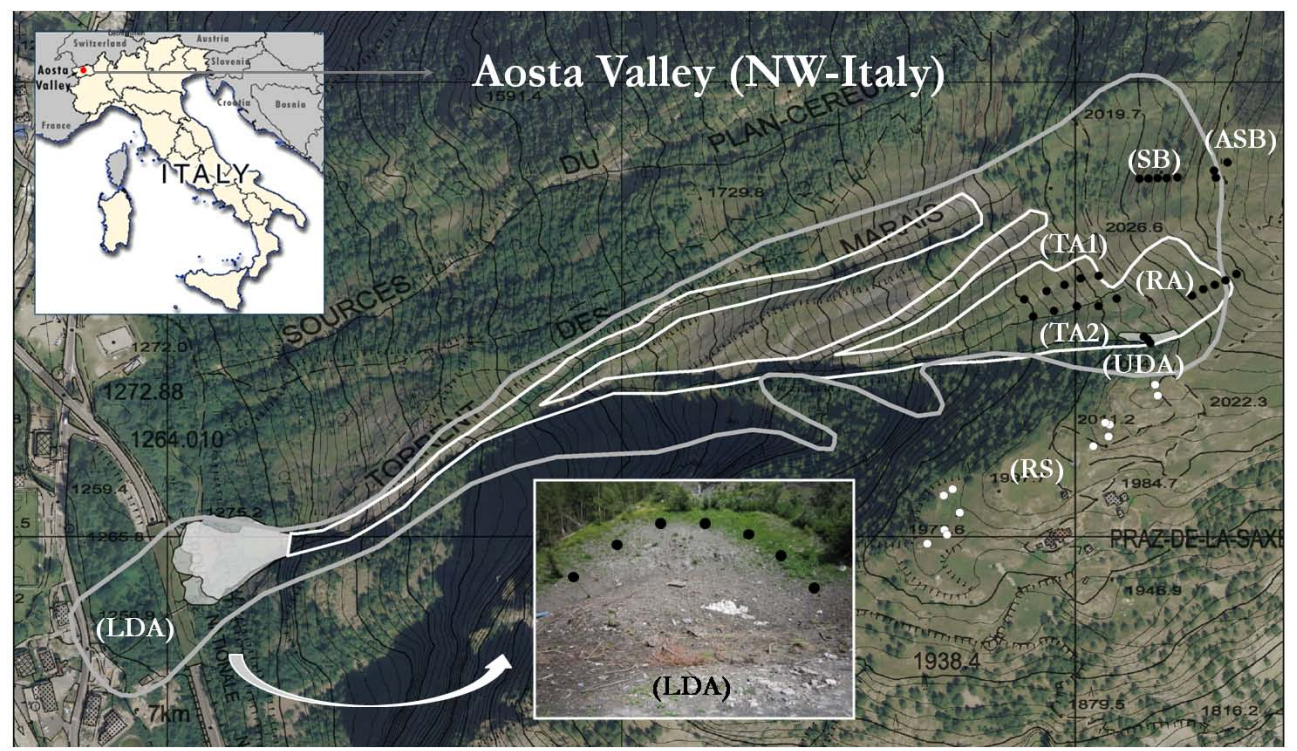

Fig. 1. Avalanche site called "Torrent de Marais - Mont De La Saxe" - Gray line: perimeter of the maximum event recorded in the Avalanches Cadastre of the Valle d'Aosta Region; white line: release and track perimeters of the events recorded in the seasons 2009 and 2010; gray areas (light and dark): avalanche deposits of the same events (source: RAVDA-Snow and Avalanche Office); white circles: sample points for Reference Site (RS); black circles: sample points for soil redistribution rates for Release Area (RA), Track Area (TA), Snow Bridge area (SB), Above Snow Bridge area (ASB), Upper Deposition Area (UDA), Lower Deposition Area (LDA).

2008/2009 and 2009/2010: high snowfall; 2010/2011: low snowfall) and the last one occurred in autumn instead of spring. However we have to consider that, historically, the Avalanche Cadastre of the Valle d'Aosta Region was used to record mainly the events involving human activities; just in the last six years the avalanche cadastre have been improved and aimed to collect all the avalanche events. Moreover interviews with locals indicate that the frequency of this kind of avalanche events (full-depth slabs of wet snow) in the last decades was constant and almost yearly. The described study area, according to the Avalanche Cadastre, is in the middle between two big districts: Val Ferret and Morgex. We intersected (ArcGis 9 - ArcMap Version 9.2) the avalanche areas (inclination $>15^{\circ}$ ), registered in the Avalanche Cadastre from 1970s, with the vegetation cover groups, got from the land use map available for the Valle d'Aosta Region. We obtained that $34 \%$ of all the avalanche release and track areas is covered by alpine pastures, the most prone to ground avalanches and related soil erosion processes thanks to their lowest roughness, $2 \%$ by hayfields and $8 \%$ by dwarf shrubs (in order of increasing roughness coefficient) (Leitinger et al., 2006).

The avalanche release area (RA) is characterized by mean steepness of $30^{\circ}$ and covered by abandoned pastures. The track area (TA) becomes much channelled ( $>35^{\circ}$ of inclination) and its coverage is composed mainly by grass. In the steepest areas, rocks and bare soil are frequent. However, the main deposition area (LDA) has a decreasing steepness and it ends on an avalanche shed, constructed in the 1970s to protect the regional road. Besides this main deposition area, there is a secondary smaller deposition area which is located at upper elevation (UDA) at $2015 \mathrm{~m}$ a.s.l., just below the release zone. A portion of the release area is covered with snow bridges (active avalanche defence structures) since 1974, and in this area (SB) the vegetation cover is mainly characterized by dwarf shrubs (Vaccinium myrtillus and Rhodondendron ferrugineum) and several larch (Larix decidua) seedlings. Just above the snow bridge, at $2110 \mathrm{~m}$ a.s.l., there's a flat area (ASB), where the inclination gently decreases, and then the slope above is again steep up to the top. Meteorological data are continuously recorded by an automatic weather station (2076 m a.s.1.) of the Ufficio Centro Funzionale (UCF) - Valle d'Aosta Region (VDA), located very close to the study area. The long-term yearly mean precipitation recorded at this station is $840 \mathrm{~mm} \mathrm{yr}^{-1}$ (period 1995-2010) and the mean annual air temperature is $+2.8^{\circ} \mathrm{C}$ (period 1993-2010) (Source: UCF-VDA). The average cumulative annual snowfall is $275 \mathrm{~cm}$ at $1250 \mathrm{~m}$ a.s.l. (period 1937-1995) and about $450 \mathrm{~cm}$ at $2000 \mathrm{~m}$ a.s.l. (Source: SMS, 2003). The bedrock is constituted mainly by black argillic schists and calcareous sandstones and, in some places, by porphyritic granites.

During the first decade of May 1986 (Chernobyl accident), north-western Italy was disturbed by both wet and dry radioactive fallout and the study area was affected by a precipitation estimated in $5-10 \mathrm{~mm}$ of rain. After a sampling campaign conducted in the Valle d'Aosta Region in 2001-2004 by ARPA Valle d'Aosta (Regional Environmental Agency), 


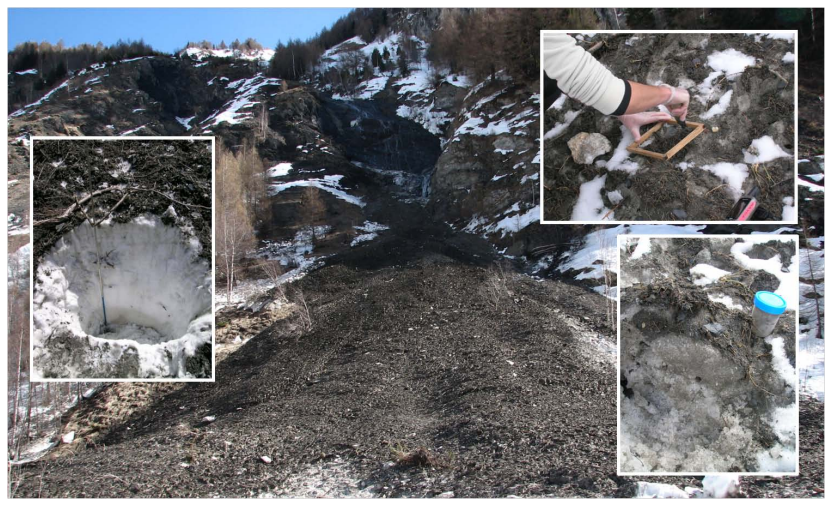

Fig. 2. Snow deposit in the Lower Deposition Area (LDA): 20082009 avalanche event. On the right a particular of the sampling method for the deposit surface (top) and for the sub-superficial snow (bottom); on the left the pit dug into the deposit.

the ${ }^{137} \mathrm{Cs}$ concentration in the soil was estimated to be in the range $0-6000 \mathrm{~Bq} \mathrm{~m}^{-2}$ (Agnesod et al., 2006). Moreover in the close Piemonte Region, it was estimated that the contribution of Chernobyl wet deposition was the major part of the global inventory $(84 \%)$, while $9 \%$ was attributable to pre-Chernobyl caesium (derived from atomic bomb testing in the atmosphere) and $7 \%$ to Chernobyl dry deposition (Facchinelli et al., 2002). Because of the proximity between the two Regions, we can consider these data most likely attributable also to our study area. This is an important assumption because if the Chernobyl input is considerably greater than the input of ${ }^{137} \mathrm{Cs}$ associated with "1960s bomb fallout", then the ${ }^{137} \mathrm{Cs}$ measurements will primarily reflect erosion occurring after 1986.

\subsection{Methodology}

\subsubsection{Snow sampling in the avalanche deposition area}

Two full-depth slab avalanche events were considered in this work: (a) one during winter season 2008-2009 (1 March 2009) and (b) the other in winter 2009-2010 (17 March 2010). Both snow avalanches caused soil erosion, with the formation of very dirty snow accumulations in the deposition zones (LDA-UDA) (Fig. 2). The release and track areas were calculated with GIS, on the basis of the georeferenced pictures taken after the avalanche events. In LDA, area and depth of the snow deposit were determined in the field as soon as the safety of the area was judged adequate. The perimeter was measured by GPS. The snow depths $(n=$ 6), for calculating the volume, were measured by a $3.5 \mathrm{~m}$ snow probe. For the purpose of sediment estimation, each avalanche deposit was surveyed two times: 17 March and 19 May during winter 2009; 2 April and 17 May during winter 2010. Snow in the main avalanche deposition zone (LDA) was sampled according to a gridded design. During win- ter 2009 the sampling points were distributed on a $7 \times 7 \mathrm{~m}$ grid square during the first sampling campaign (17 March $(n=58))$ then on a $15 \times 15 \mathrm{~m}$ grid square during the second campaign (19 May $(n=10)$ ). Sampling in 2010 was conducted at a lower spatial resolution, using a $20 \times 20 \mathrm{~m}$ grid square in both sampling events (2 April $(n=8), 17$ May $(n=6))$. The sampling points were mapped by GPS (accuracy $<5 \mathrm{~m}$ ). We chose to sample the surface and the inner body of the avalanche deposit in order to investigate the vertical distribution of sediments. Superficial samples were collected on a constant area, by a wooden made rectangular mask of $0.15 \times 0.15 \mathrm{~m}$ in order to: (a) make easier and faster the sampling campaign as the avalanche run out area was an unsafe zone; (b) try to avoid the extreme "topographical" irregularity of the deposit surface. In the inner body snow samples were collected at $0.20 \mathrm{~m}$ below the surface using a plastic core (fixed volume of $0.15 \mathrm{dm}^{3}$ ). Moreover a snow pit was dug down to the ground in the avalanche deposit during spring 2009 and 5 samples $\left(0.15 \mathrm{dm}^{3}\right)$ were collected in order to analyze the debris distribution along the deposit profile (Fig. 2). During the sampling we observed that most part of the sediment was represented by "soil", a mixture of small mineral and organic particles. We excluded large organic debris and rocks with a diameter greater than $5 \mathrm{~cm}$.

\subsubsection{Estimates of snow related soil redistribution rates by avalanche deposit data}

The samples, collected into the Lower Deposition Area (LDA), were melted and filtered through a $0.45 \mu \mathrm{m}$ filter, using a vacuum pump. The filtered material was dried $\left(40^{\circ} \mathrm{C}\right)$ and weighted to obtain the concentration of sediment $(C)$. The sediment mean values were used to estimate the sediment load in the run-out area by multiplying with the avalanche deposit volume $(V)$. The sediment load was calculated for both the deposit surface layer $(V=$ deposit surface area $\times$ snow depth of the superficial layer (a constant value of $0.02 \mathrm{~m}$ was estimated)) and for the rest of the snow deposit ( $V=$ deposit surface area $\times$ deposit mean depth). The average soil deposition rate was calculated dividing the total sediment load of each event by the deposition area. This mass accumulation rate was converted into a rate of soil accretion dividing the soil deposition rate by the unconsolidated debris density of $1200 \mathrm{~kg} \mathrm{~m}^{-3}$ (Freppaz et al., 2010). The average soil erosion rate for each event was calculated dividing the total sediment load by the sum of avalanche release and track areas. Concerning the sediment mean concentration values $(C)$, we calculated the standard error $( \pm \mathrm{SE})$ and we expanded it to the soil accumulation and erosion rates.

\subsubsection{Soil sampling along the avalanche path}

Soil samples were collected during summer season 2010, using a $72 \mathrm{~mm}$ diameter soil core sampler, (Giddings Machine Company, Windsor, CO, USA). The site for the reference 
inventory (RS), that represents the original ${ }^{137} \mathrm{Cs}$ activity without soil redistribution processes, was selected very close to the study area in a flat and undisturbed position at $2000 \mathrm{~m}$ a.s.l. We took 11 soil profiles from the reference site: three soil samples, which were a bulk of three replicates taken within $1 \mathrm{~m}^{2}$, were used to determine average profile distribution and maximum depth of ${ }^{137} \mathrm{Cs}$, while eight more samples were used to investigate its spatial variability and to determine the ${ }^{137} \mathrm{Cs}$ base line. For estimating redistribution rates soil cores were collected along altitudinal transects in the three sites SB, RA and TA; just for the track area (TA) we chose to sample two transects (TA1 and TA2) instead of one because of the wider extension of this area compared to the others. For each transect 5 cores were taken every $15 \mathrm{~m}$. From these cores the upper $9 \mathrm{~cm}$ were separated from the lower soil profile, in order to differentiate the physicochemical properties of topsoil from the subsoil. In the lower main avalanche deposition area (LDA) 7 samples were collected and bulked together every $5 \mathrm{~cm}$, while three sites were sampled in the upper deposition area (UDA) and other three in the flat area above the snow bridge (ASB) (Fig. 1).

\subsubsection{Soil samples pre-treatment and laboratory analyses}

In total 62 soil cores were sampled, and from them 136 subsamples were oven-dried at $40^{\circ} \mathrm{C}$, lightly ground and sieved $(<2 \mathrm{~mm})$. An aliquot of each sample was put into a 25 $\mathrm{ml}$ container $(6.5 \mathrm{~cm}$ diameter; Semadeni25) and analyzed for $8 \mathrm{~h}$ with a Lithium-drifted Germanium detector (GeLi; PrincetonGamma-Tech, Princeton, NJ, USA) at the Department for Physics and Astronomy, University of Basel. The size of the detector was $48 \mathrm{~mm}$ in diameter and $50 \mathrm{~mm}$ in length. The relative efficiency was $18.7 \%$. In order to reduce the amount of radiation from background sources into the environment, the samples were shielded by 4-cm-thick lead during measurement. The ${ }^{137} \mathrm{Cs}$ activity concentrations were determined using the Inter Winner 5 gamma spectroscopy software (Ortec, Oak Ridge, TN, USA). The energy calibration of the GeLi detector was done using a Eu-152 multisource with peak line positions at 117.6, 347.6, 773.5, 1108.0 and $1408.9 \mathrm{keV}$. For efficiency calibration, three referencesamples provided by H. Surbeck (University of Neuchâtel) enriched with known activities of U-238, Th-232 and K-40, were used. These calibration samples were of the same geometry and a comparable density as our analysed soil samples. The resulting measurement uncertainty on ${ }^{137} \mathrm{Cs}$ peak area (at $661 \mathrm{keV}$ ) was lower than $15 \%$ (error of the measurement at 2-sigma). The minimum detection activity for ${ }^{137} \mathrm{Cs}$ was $0.1 \mathrm{~Bq} \mathrm{~kg}^{-1}$. In order to make sure that the gamma spectroscopy system is working correctly and yields reliable results, the reference material IAEA-375 was measured every second week.

Soil cores from each sampling site were roughly described during the sample preparation and 17 of them (for 46 sub- samples in total) were analyzed for the determination of the main physical and chemical properties. The measured physical parameters were: skeleton content (\%), bulk density $\left(\mathrm{kg} \mathrm{m}^{-3}\right)$, particle size distribution (\%) measured by the wet sieving method for sand fractions and by the sedimentation method (using the SediGraph 5100 Particle size Analysis System) for the silt and clay fractions. The chemical parameters analyzed were: $\mathrm{pH}_{\mathrm{H}_{2} \mathrm{O}}$, total organic (TOC) carbon content (\%) measured by the RC612 Multiphase Carbon and Hydrogen/Moisture Analyzer, total nitrogen content (TN \%) measured by the LECOCHN-1000 Carbon, Hydrogen and Nitrogen Analyser.

\subsubsection{Conversion of ${ }^{137} \mathrm{Cs}$ measurements in estimates of soil redistribution rates}

The profile distribution model is most commonly used for undisturbed stable soils, where the distribution of ${ }^{137} \mathrm{Cs}$ shows an exponential decline with depth, which may be described by the following function (Walling and Quine, 1990; Zhang et al., 1990):

$A^{\prime}(x)=A_{\text {ref }}\left(1-e^{x / h_{o}}\right)$

where: $A^{\prime}(x)=$ amount of ${ }^{137} \mathrm{Cs}$ above the depth $x\left(\mathrm{~Bq} \mathrm{~m}^{-2}\right)$, $x=$ depth from soil surface expressed as mass between top and actual depth $\left(\mathrm{kg} \mathrm{m}^{-2}\right), A_{\text {ref }}={ }^{137} \mathrm{Cs}$ reference inventory $\left(\mathrm{Bq} \mathrm{m}^{-2}\right), h_{o}=$ profile shape factor $\left(\mathrm{kg} \mathrm{m}^{-2}\right)$ that is a coefficient describing the rate of exponential decrease in inventory with depth, for soil profiles in uncultivated sites.

If it is assumed that the total ${ }^{137} \mathrm{Cs}$ fallout occurred in 1986 and that the depth distribution of the ${ }^{137} \mathrm{Cs}$ in the soil profile is independent of time, the erosion rate $Y$ for an eroding point (with total ${ }^{137} \mathrm{Cs}$ inventory $A_{u}\left(\mathrm{~Bq} \mathrm{~m}^{-2}\right)$ less than the local reference inventory $A_{\text {ref }}\left(\mathrm{Bq} \mathrm{m}^{-2}\right)$ ) can be expressed as (Walling and Quine, 1990; Zhang et al., 1990):

$Y=10 /(t-1986) \times \ln (1-X / 100) \times h_{o}$

$Y=$ erosion rate $\left(\mathrm{Mg} \mathrm{ha}^{-1} \mathrm{yr}^{-1}\right), t=$ year of sampling, 1986 $=$ because in Valle d'Aosta Region the contribution of Chernobyl wet deposition was the major part of the global inventory $(84 \%), X=\%$ reduction of ${ }^{137} \mathrm{Cs}$ total inventory in respect to the local ${ }^{137} \mathrm{Cs}$ reference value (defined as: $\left.\left(A_{\text {ref }}-A_{u}\right) / A_{\text {ref }} \times 100\right)$.

The profile distribution model is simple and easy to use. However, this model involves a number of simplifying assumptions and does not take into account the time dependent nature of the ${ }^{137} \mathrm{Cs}$ fallout migration in the soil and the progressive evolution of the depth distribution of the ${ }^{137} \mathrm{Cs}$ within the soil profile after deposition from the atmosphere. Consequently, it is likely to overestimate rates of soil loss if long time periods are investigated (Walling and He, 1999).

However, in our study area with ${ }^{137} \mathrm{Cs}$ input predominantly (>80\%) from Chernobyl (1986), the application of this model was most suitable because it was possible to assume that the time span for migration of ${ }^{137} \mathrm{Cs}$ was too short. 
Table 1. Main characteristics of the two snow avalanches (2009 and 2010) with the mean concentration values ( \pm SE) of the sediment transported into the Lower Deposition Area (LDA) and with the relative soil accumulation and erosion rates.

\begin{tabular}{|c|c|c|c|c|c|c|}
\hline AVALANCHE EVENTS (year) & \multicolumn{3}{|c|}{ Winter 2008/2009 } & \multicolumn{3}{|c|}{ Winter 2009/2010 } \\
\hline \multirow{3}{*}{$\begin{array}{l}\text { Release }+ \text { track area }\left(\mathrm{m}^{2}\right) \\
\text { Deposition area }(\mathrm{LDA})\left(\mathrm{m}^{2}\right)\end{array}$} & & 50796 & & & 60440 & \\
\hline & & 6889 & & & 7810 & \\
\hline & $\begin{array}{l}\text { Deposit } \\
\text { Surface }\end{array}$ & $\begin{array}{l}\text { Deposit } \\
\text { Inner Body }\end{array}$ & Total & $\begin{array}{l}\text { Deposit } \\
\text { Surface }\end{array}$ & $\begin{array}{l}\text { Deposit } \\
\text { Inner Body }\end{array}$ & Total \\
\hline Deposition depth (m) & 0.02 & $1.36 \pm 0.20$ & & 0.02 & $1.68 \pm 0.22$ & \\
\hline Deposition volume $\left(\mathrm{m}^{3}\right)$ & 138 & 10334 & 10471 & 107 & 11715 & 11822 \\
\hline Sediment concentration $\left(\mathrm{kg} \mathrm{m}^{-3}\right)$ & $118.65 \pm 12.81$ & $0.25 \pm 0.04$ & & $816.40 \pm 177.81$ & $1.82 \pm 0.37$ & \\
\hline Sediment load $(\mathrm{kg})$ & $16348 \pm 1765$ & $2618 \pm 402$ & $18965 \pm 2167$ & $104425 \pm 22845$ & $21282 \pm 4333$ & $125708 \pm 27178$ \\
\hline Deposition rate $\left(\mathrm{Mg} \mathrm{ha}^{-1}\right)$ & $23.7 \pm 2.6$ & $3.8 \pm 0.6$ & $27.5 \pm 3.1$ & $133.7 \pm 29.3$ & $27.3 \pm 5.5$ & $161.0 \pm 34.8$ \\
\hline Soil accretion $(\mathrm{mm})$ & $1.98 \pm 0.21$ & $0.32 \pm 0.05$ & $2.29 \pm 0.26$ & $11.14 \pm 2.44)$ & $2.27 \pm 0.46$ & $13.41 \pm 2.90$ \\
\hline Erosion rate $\left(\mathrm{Mg} \mathrm{ha}^{-1}\right)$ & $3.2 \pm 0.3$ & $0.5 \pm 0.1$ & $3.7 \pm 0.4$ & $17.3 \pm 3.8$ & $3.5 \pm 0.7$ & $20.8 \pm 4.5$ \\
\hline Soil erosion $(\mathrm{mm})$ & $0.27 \pm 0.03$ & $0.04 \pm 0.01$ & $0.31 \pm 0.04$ & $1.44 \pm 0.31$ & $0.29 \pm 0.06$ & $1.73 \pm 0.37$ \\
\hline
\end{tabular}

Statistical analysis of the data was carried out using SPSS 17.0 (SPSS Inc., Chicago, 15 IL). Another source of uncertainty resulted from the variability of the ${ }^{137} \mathrm{Cs}$ inventory in the reference site and from the extrapolation of the erosion rates measured on point scale to catchment scale. The latter was necessary to allow a comparison between the soil redistribution rates determined with the two methods.

\section{Results and discussion}

\subsection{Assessment of snow related soil deposition rates using the conventional approach}

In the two considered events (years 2009 and 2010) volume and areas of the avalanche deposits were comparable. The area was 10 times smaller than the one registered as the maximum event in the Regional Avalanche Cadastre (6.5 ha) (Fig. 1). The measured mean depths of the two events were similar $(1.36 \pm 0.20 \mathrm{~m}$ and $1.68 \pm 0.22 \mathrm{~m})$ and we used the average value of $1.52 \pm 0.21 \mathrm{~m}$, rounded down to $1.50 \mathrm{~m}$ for the calculation of the inner body volume. In the 2010 event the amount of sediment transported was seven times higher than in the 2009 event. In both years most part of the sediment was concentrated in the upper centimetres of the snow deposit, as shown also in other studies (Jomelli and Bertran, 2001; Heckmann, 2002). In the superficial part of the avalanche deposit the sediment concentrations were more than four hundreds times higher than in the inner body with mean values of the two events equal to $467.53 \pm 95.31 \mathrm{~kg} \mathrm{~m}^{-3}$ and $1.04 \pm 0.20 \mathrm{~kg} \mathrm{~m}^{-3}$, respectively. Also the sediment loads from the surface layer $(60386 \pm 12305 \mathrm{~kg})$ were five times higher than the loads derived from the inner body $(11950 \pm 2367 \mathrm{~kg})$. Sediment concentration and load values were consistent with the values reported in literature (Ackroyd, 1987; Jomelli and Bertran, 2001; Heckmann, 2002). The snow related soil deposition rates, estimated by the avalanche deposit data, were $27.5 \pm 3.1 \mathrm{Mg} \mathrm{ha}^{-1}$ and $161.0 \pm 34.8 \mathrm{Mg} \mathrm{ha}^{-1}$, for 2009 and 2010 events, respectively. These values were comparable to data $\left(9.7-240.8 \mathrm{Mg} \mathrm{ha}^{-1}\right.$ event $\left.^{-1}\right)$ referred to an avalanche path located close to the study area (Freppaz et al., 2010). The soil accretion values, resulting from the sediment accumulation, were $2.29 \pm 0.26 \mathrm{~mm}$ and $13.41 \pm 2.90 \mathrm{~mm}$, for 2009 and 2010 events, respectively (Table 1). Considering that one avalanche event occurred per season, we could assume these data as yearly rates of snow related soil deposition, and they were in the range of values $\left(0.3-4.8 \mathrm{~mm} \mathrm{yr}^{-1}\right)$ reported in the previous literature (Caine, 1969a; Luckman, 1971, 1978).

The pit dug in the avalanche body down to the ground to sample the snow vertically (Fig. 2) confirmed that the sediment was concentrated in the upper few $\mathrm{cm}$ of the snow deposit and that in the inner body it was homogeneously distributed $\left(0.25 \pm 0.04 \mathrm{~kg} \mathrm{~m}^{-3}\right)$, revealing a good vertical mixing of sediments. Regarding the spatial distribution of sediments at the deposit surface, the geostatistical analyses (ArcGis 9 - ArcMap Version 9.2) did not show a clear pattern. The total absence of a sediment distribution pattern in the run-out area might be explained by the morphological characteristics of the avalanche path and by the kind of avalanche (full-depth slab, wet snow). The avalanche path is very steep and channelled in the lower track area and suddenly the steepness decreases in the run-out area, so that we could hypothesize that the heavy mass of wet snow suddenly stopped without the space and power necessary to run more and to redistribute the sediments horizontally. 
Table 2. Main physico-chemical characteristics of the investigated soils (average values).

\begin{tabular}{lrrrrrrrrrr}
\hline Site & $\begin{array}{r}\text { Total } \\
\text { Depth }(\mathrm{cm})\end{array}$ & Samples & $\begin{array}{r}\text { Skeleton } \\
(>2 \mathrm{~mm}) \%\end{array}$ & $\begin{array}{r}\text { Sand } \\
\%\end{array}$ & $\begin{array}{r}\text { Silt } \\
\%\end{array}$ & $\begin{array}{r}\text { Clay } \\
\%\end{array}$ & $\begin{array}{r}\text { Bulk Density } \\
\mathrm{kg} \mathrm{m}^{-3}\end{array}$ & $\begin{array}{r}\mathrm{pH} \\
\%\end{array}$ & $\begin{array}{r}\text { TOC } \\
\%\end{array}$ & $\begin{array}{r}\mathrm{C} / \mathrm{N} \\
\text { RS }\end{array}$ \\
& $30-40$ & $(0-18 \mathrm{~cm})$ & 5 & 50.0 & 40.2 & 9.8 & 908 & 5.4 & 4.1 & 10 \\
& & $(18 \mathrm{~cm}+)$ & 27 & 59.9 & 33.5 & 6.7 & 1198 & 5.3 & 0.7 & 7 \\
RA & $50-60$ & $(0-9 \mathrm{~cm})$ & 41 & 35.4 & 38.2 & 9.7 & 1073 & 4.3 & 3.3 & 7 \\
& & $(9 \mathrm{~cm}+)$ & 47 & 37.9 & 34.6 & 10.8 & 1073 & 4.0 & 1.3 & 5 \\
TA & $50-60$ & $(0-9 \mathrm{~cm})$ & 31 & 32.2 & 33.2 & 9.5 & 908 & 5.4 & 3.8 & 8 \\
& & $(9 \mathrm{~cm}+)$ & 42 & 33.5 & 30.2 & 11.4 & 1137 & 5.4 & 1.2 & 5 \\
SB & $40-50$ & $(0-9 \mathrm{~cm})$ & 33 & 39.0 & 46.9 & 14.1 & 659 & 5.2 & 4.9 & 10 \\
& & $(9 \mathrm{~cm}+)$ & 38 & 38.1 & 42.1 & 19.8 & 1085 & 5.0 & 2.3 & 8 \\
UDA & $40-50$ & $(0-30 \mathrm{~cm})$ & 43 & 45.5 & 40.8 & 13.7 & 1206 & 6.0 & 2.9 & 9 \\
LDA & $40-50$ & $(0-50 \mathrm{~cm})$ & 60 & 56.1 & 37.3 & 6.6 & 1348 & 8.0 & 1.6 & 8 \\
ASB & $30-40$ & $(0-18 \mathrm{~cm})$ & 12 & 38.4 & 47.9 & 13.7 & 875 & 5.0 & 5.6 & 9 \\
& & $(18 \mathrm{~cm}+)$ & 27 & 49.0 & 37.8 & 13.3 & 1132 & 4.8 & 2.1 & 6 \\
\hline
\end{tabular}

\subsection{Assessment of snow related soil erosion rates using the conventional approach}

In the considered events (2009 and 2010) the avalanche release and track zones had almost the same shape and the area was equal to about one third of the area of the maximum event reported in the Regional Avalanche Cadastre (18.1 ha) (Fig. 1). The soil erosion rates, estimated assuming that the source of the total sediment load was uniformly distributed over the entire avalanche release and track areas, were $3.7 \pm 0.4 \mathrm{Mg} \mathrm{ha}^{-1}$ event $^{-1}$ and $20.8 \pm 4.5 \mathrm{Mg} \mathrm{ha}^{-1}$ event $^{-1}$, corresponding to a soil layer of $0.31 \pm 0.04 \mathrm{~mm}$ and $1.73 \pm 0.37 \mathrm{~mm}$, respectively for 2009 and 2010 events (Table 1). As for the deposition rates, since one avalanche event occurred per season, we could consider these data as yearly rates of snow related soil erosion. The erosion rates, were comprised into the wide range $\left(1-100 \mathrm{Mg} \mathrm{ha}^{-1} \mathrm{yr}^{-1}\right)$ reported by Bozhinskiy and Losev (1998) and referred to the annual removal of mineral material caused by avalanches in areas of Russia at different elevation zones.

\subsection{Soil characterization of reference site and evaluation of the ${ }^{137} \mathrm{Cs}$ baseline level}

In the reference site (RS) the upper horizons showed a well developed polyhedral and granular structure, while the subsoil had a weaker structure and a higher skeleton content (Table 2). The mass activity in the first $3 \mathrm{~cm}$ ranged between $28.8 \pm 8.1 \mathrm{~Bq} \mathrm{~kg}^{-1}$ and $72.0 \pm 13.2 \mathrm{~Bq} \mathrm{~kg}^{-1}$ and exponentially decreased to an average of $13.6 \pm 3.7 \mathrm{~Bq} \mathrm{~kg}^{-1}$ in the $9-12 \mathrm{~cm}$ soil increment. No caesium was detected below the $12 \mathrm{~cm}$ layer. Considering the average areal activity density $\left(\mathrm{Bq} \mathrm{m}^{-2}\right)$, calculated on the bases of the soil density, most of ${ }^{137} \mathrm{Cs}(87 \%)$ was accumulated in the upper $9 \mathrm{~cm}$ (Fig. 3). The total ${ }^{137} \mathrm{Cs}$ areal activity of the reference inventories ranged from 2.62 to $4.45 \mathrm{kBq} \mathrm{m}^{-2}$. The average value of $3.59 \mathrm{kBq} \mathrm{m}^{-2}$, with a coefficient of variation $(\mathrm{CV})$ of $22.3 \%$, corresponded to the caesium baseline level, which was the residual amount left from the historical ${ }^{137} \mathrm{Cs}$ fallout inputs, in absence of erosion or deposition. This baseline level was within the range $\left(0-6000 \mathrm{~Bq} \mathrm{~m}^{-2}\right)$ of caesium concentrations in the soil, reported for the study area after a measuring campaign conducted by ARPA Valle d'Aosta between 2001 and 2004 (Agnesod et al., 2006). Moreover the coefficient of variation $(22.3 \%)$ was within the range of results reported in other studies carried out on reference sites (Sutherland, 1991, 1996; Owens and Walling, 1996).

\subsection{Assessment of total soil deposition rates using ${ }^{137} \mathrm{Cs}$ approach}

In ASB the ${ }^{137} \mathrm{Cs}$ mass activity density was maximum in the upper soil layer, with an exponential decrease towards depth (Fig. 4). In UDA the average total areal activity was $12.76 \mathrm{kBq} \mathrm{m}^{-2}$ with a maximum activity in the $3-6$ and $21-$ $24 \mathrm{~cm}$ soil layers (Fig. 5). In LDA the total areal activity was $13.33 \mathrm{kBq} \mathrm{m}^{-2}$ with a greater activity in the upper soil horizons $(0-15 \mathrm{~cm})$, and the maximum in the $10-15 \mathrm{~cm}$ soil layer, equivalent to $2.70 \mathrm{kBq} \mathrm{m}^{-2}$.

Converting the ${ }^{137} \mathrm{Cs}$ inventories to soil redistribution rates, the avalanche deposition areas (UDA and LDA) and the site above snow bridge (ASB), showed a clear sedimentation process. The deposition rates in ASB ranged between 5.3 and $11.6 \mathrm{Mg} \mathrm{ha}^{-1} \mathrm{yr}^{-1}$ and the average value $\left(8.9 \mathrm{Mg} \mathrm{ha}^{-1} \mathrm{yr}^{-1}\right)$, even if not significantly $(p=0.094)$, was globally lower than in the deposition areas (average between LDA and UDA of $12.3 \mathrm{Mg} \mathrm{ha}^{-1} \mathrm{yr}^{-1}$ ). The sedimentation rate in the avalanche deposition sites ranged between 11.0 and $13.2 \mathrm{Mg} \mathrm{ha}^{-1} \mathrm{yr}^{-1}$ in UDA and was equal to $12.6 \mathrm{Mg} \mathrm{ha}^{-1} \mathrm{yr}^{-1}$ in LDA (Figs. 6 and 7). Taking into account the average bulk density of the different soil layers, the soil accretion was estimated at $1.05 \mathrm{~mm} \mathrm{yr}^{-1}$ and 


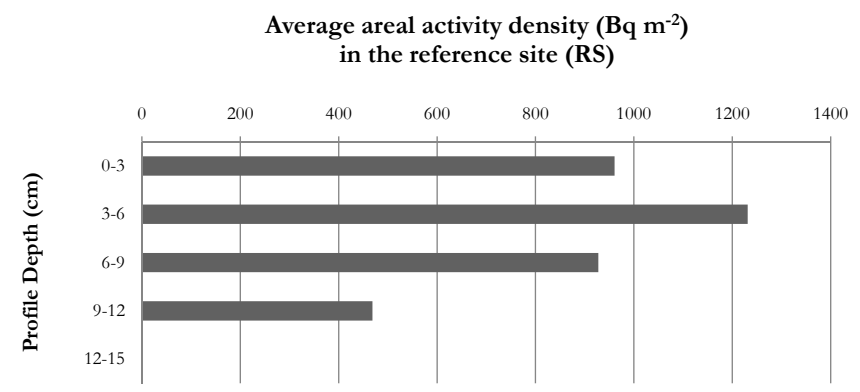

Fig. 3. Mean depth distribution of ${ }^{137} \mathrm{Cs}\left(\mathrm{Bq} \mathrm{m}^{-2}\right)$ in the soil of reference site. The sum of the average areal activity density reported for each $3 \mathrm{~cm}$ layer is the ${ }^{137} \mathrm{Cs}$ baseline level.

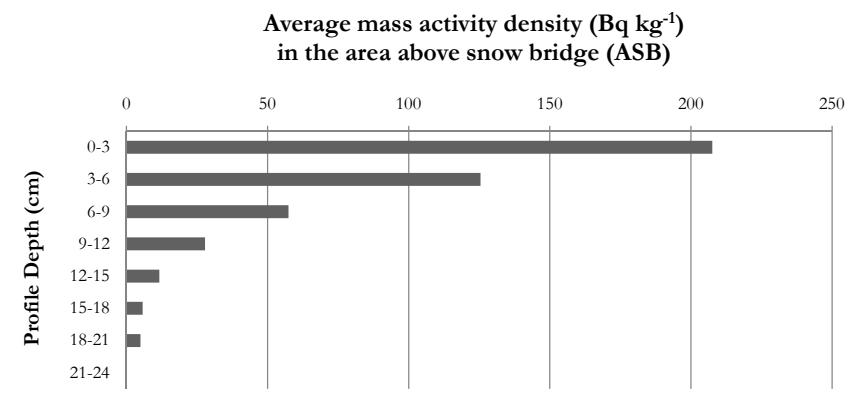

Fig. 4. Mean depth distribution of ${ }^{137} \mathrm{Cs}\left(\mathrm{Bq} \mathrm{kg}^{-1}\right)$ in the soil of the area Above Snow Bridge (ASB).

$0.93 \mathrm{~mm} \mathrm{yr}^{-1}$, equivalent to a total deposition during the 24yr period (1986-2010) of $25.10 \mathrm{~mm}$ and $22.40 \mathrm{~mm}$, in UDA and LDA respectively. In ASB the associated soil accretion rate was $0.84 \mathrm{~mm} \mathrm{yr}^{-1}$, equivalent to a total deposition during the 24-yr period (1986-2010) of $20.23 \mathrm{~mm}$.

In the upper (UDA) and lower (LDA) deposition areas the soils, compared to all the other sites, were characterized by the highest skeleton content $(52 \%)$ and bulk density $\left(1277 \mathrm{~kg} \mathrm{~m}^{-3}\right)$, while in the area above the snow bridges (ASB) soils had lower skeleton content (average of 19\%) and bulk density (average of $1003 \mathrm{~kg} \mathrm{~m}^{-3}$ ) (Table 2). Considering the even lower amount of skeleton $(12 \%)$ found in the upper soil horizon of ASB, it seemed that here mainly fine particles accumulate. In early spring 2011, just after the snow melt and before any rain storms, a clear sedimentation of fine particle was visible (Fig. 8). Therefore in ASB, usually not interested by ground avalanches, we could assume that, besides the runoff processes, also snowmelt and snow gliding, in this case without enough force to transport stones, may actively contribute to the total soil erosion.

\subsection{Assessment of total soil erosion rates using ${ }^{137}$ Cs approach}

In the avalanche release (RA) and track areas (TA) the soils were frequently disturbed with the removal of the upper horizons and the exposure of the subsoil, while in the snow

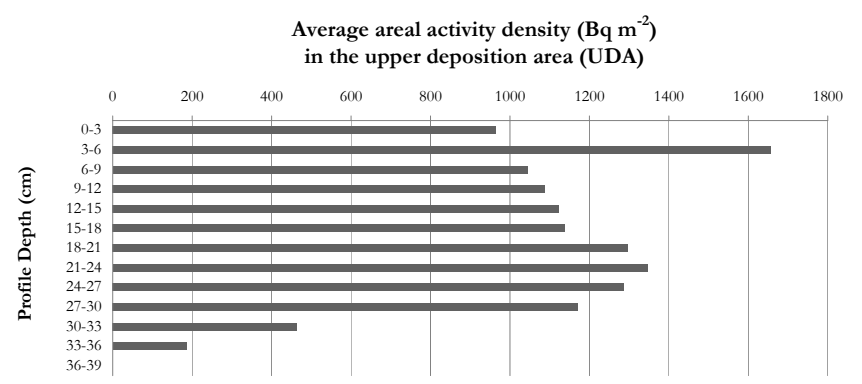

Fig. 5. Mean depth distribution of ${ }^{137} \mathrm{Cs}\left(\mathrm{Bq} \mathrm{m}^{-2}\right)$ in the soil of the upper deposition area (UDA).

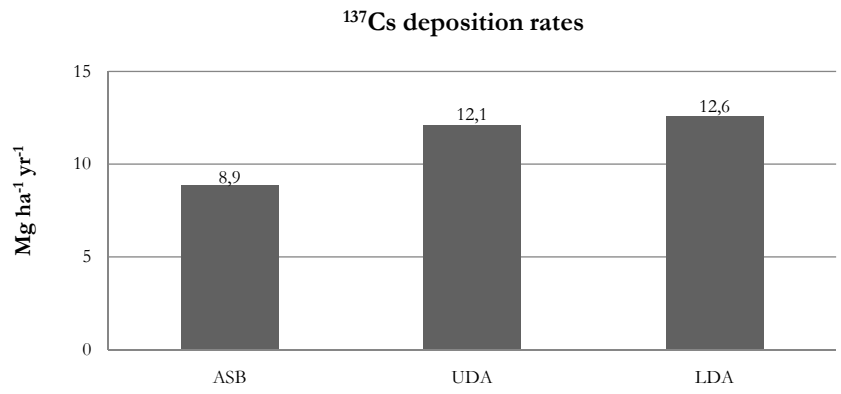

Fig. 6. Soil deposition rates in the area Above the Snow Bridges (ASB), in the Upper Deposition Area (UDA) and in the Lower Deposition Area (LDA).

bridges area (SB) no evident erosion was present. Looking at the properties of the upper horizons in the reference site (RS) and in RA, TA and SB, the soil density ranged between $659 \mathrm{~kg} \mathrm{~m}^{-3}$ in SB and $1073 \mathrm{~kg} \mathrm{~m}^{-3}$ in RA and the skeleton content was the highest in RA (41\%) and the lowest in RS $(5 \%)$. The high percentage of skeleton content, except for RS, could confirm that in RA and TA the deeper horizons became exposed to the surface after the erosion of the upper horizons, while in SB the soils were more likely disturbed during the snow bridge construction. The organic carbon content was higher in RS $(4.1 \%)$ and SB $(4.9 \%)$ and lower in RA $(3.3 \%)$ and TA (3.8\%), showing that in SB, where also the soil density was the lowest, the vegetation cover seemed to have better stabilized the soil (Table 2).

The mean ${ }^{137} \mathrm{Cs}$ activity in RA was $37.3 \pm 6.5 \mathrm{~Bq} \mathrm{~kg}^{-1}$, while values of $74.0 \pm 6.2 \mathrm{~Bq} \mathrm{~kg}^{-1}$ and $61.4 \pm 9.8 \mathrm{~Bq} \mathrm{~kg}^{-1}$ were found in TA1 and TA2 transects, respectively. In SB the mean ${ }^{137} \mathrm{Cs}$ activity was equal to $62.8 \pm 5.1 \mathrm{~Bq} \mathrm{~kg}^{-1}$, with an increasing trend down the slope. Converting the ${ }^{137} \mathrm{Cs}$ inventories to soil erosion rates, using the profile distribution model, the values confirmed that in these areas erosion phenomena occurred, except for the point at lowest altitude in the SB transect. The SB site showed a decreasing trend in soil erosion rates from the highest to the lowest sampling point, with $-30.0 \mathrm{Mg} \mathrm{ha}^{-1} \mathrm{yr}^{-1}$ and $+0.3 \mathrm{Mg} \mathrm{ha}^{-1} \mathrm{yr}^{-1}$, respectively (Fig. 7). This phenomenon could be due to the protection effect of the avalanche defence 
${ }^{137}$ Cs redistribution rates

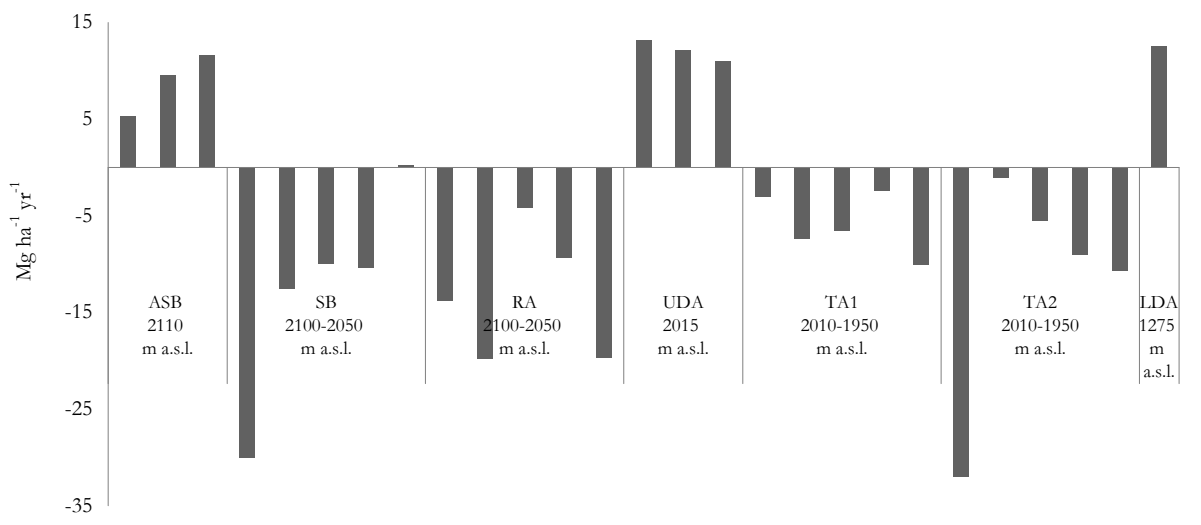

Fig. 7. Soil redistribution rates in all the sampling sites: Snow Bridge area (SB); Above Snow Bridge area (ASB), Release Area (RA); Upper Deposition Area (UDA), Track Area (TA), Lower Deposition Area (LDA). Negative values indicate erosion, while positive ones indicate accumulation. In each transect (SB, RA and TA) the first point in the graph is at highest elevation while the fifth is at lowest elevation.

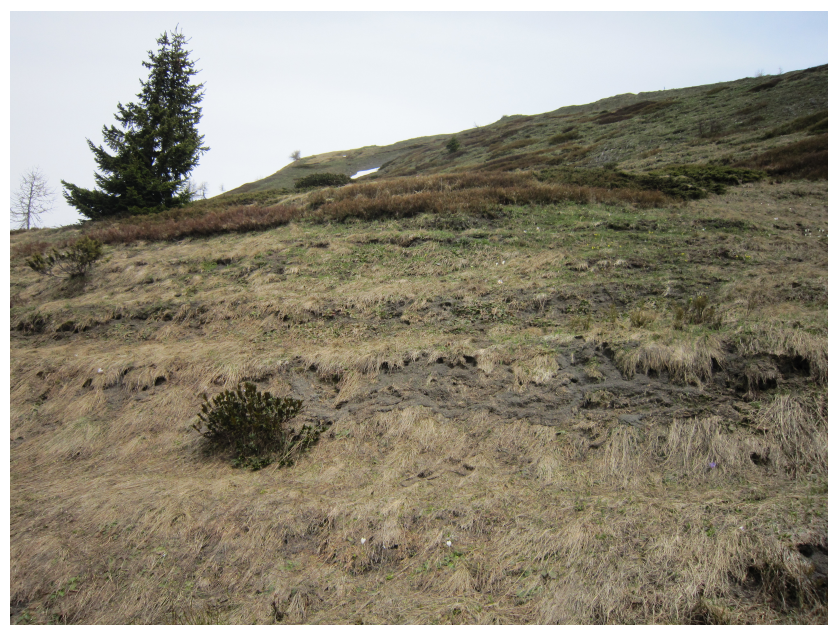

Fig. 8. Particle sedimentation in the Above Snow Bridges (ASB) area after the snow melting.

structures. It seemed that snow bridges have also an influence on soil erosion processes, allowing the colonization by shrubs and larch seedlings. In the other transects the erosion values were more variable and without any trends along the slope. Considering the mean erosion rates in the different areas no significant differences $(p<0.05)$ were found (Fig. 9), even if a lower value was observed in the TA $\left(8.8 \mathrm{Mg} \mathrm{ha}^{-1} \mathrm{yr}^{-1}\right.$ vs. $13.4 \mathrm{Mg} \mathrm{ha}^{-1} \mathrm{yr}^{-1}$ in RA and $12.6 \mathrm{Mg} \mathrm{ha}^{-1} \mathrm{yr}^{-1}$ in SB). These values were in the range of yearly values $\left(7-37 \mathrm{Mg} \mathrm{ha}^{-1} \mathrm{yr}^{-1}\right.$ ) determined, also with the ${ }^{137}$ Cs method, by Konz et al. $(2009,2010)$ for steep alpine slopes in the Central Swiss Alps, which were also partly heavily affected by avalanche activity. Taking into account the mean bulk density of the different soil layers, the erosion rates ranged between $0.97 \mathrm{~mm} \mathrm{yr}^{-1}$ and $1.90 \mathrm{~mm} \mathrm{yr}^{-1}$ in TA and $\mathrm{SB}$, equivalent to a total soil erosion, during the 24 -yr period (1986-2010) of $23.29 \mathrm{~mm}$ and $45.71 \mathrm{~mm}$, respectively.

\subsection{Comparison between the conventional and the ${ }^{137} \mathrm{Cs}$ approaches}

The yearly sedimentation rate $\left(12.6 \mathrm{Mg} \mathrm{ha}^{-1} \mathrm{yr}^{-1}\right.$, corresponding to a soil accretion of $0.93 \mathrm{~mm} \mathrm{yr}^{-1}$ ) measured by ${ }^{137} \mathrm{Cs}$ in LDA were lower but comparable with the estimates done using data from the avalanche deposit area (27.5 $\mathrm{Mg} \mathrm{ha}^{-1}$ event $^{-1}$ and $161.0 \mathrm{Mg} \mathrm{ha}^{-1}$ event $^{-1}$ with an estimated soil accretion ranging between $2.29 \mathrm{~mm}^{-1}$ event $^{-1}$ and $13.41 \mathrm{~mm}_{\text {event }}{ }^{-1}$ ). In LDA the effective ${ }^{137} \mathrm{Cs}$ value could be likely higher: the sampling points were chosen in a rather steep area in the deposition zone (greater than $15^{\circ}$ ); it was not possible to exclude soil erosion for example by runoff, but it was not disturbed by human activity. Moreover, these results, both from conventional and ${ }^{137} \mathrm{Cs}$ approaches, were higher (about ten times) than the values reported by Lana-Renault et al. (2011), who, in a field experiment in a Mediterranean high mountain catchment, found a yearly sediment yield, due to runoff processes, ranging between $2.1 \mathrm{Mg} \mathrm{ha}^{-1} \mathrm{yr}^{-1}$ and $2.9 \mathrm{Mg} \mathrm{ha}^{-1} \mathrm{yr}^{-1}$ (43-35\% of which due to snowmelt runoff).

The average ${ }^{137} \mathrm{Cs}$ erosion rates in $\mathrm{RA}$ and $\mathrm{TA}$ (13.4 $\mathrm{Mg} \mathrm{ha}^{-1} \mathrm{yr}^{-1}$ and $8.8 \mathrm{Mg} \mathrm{ha}^{-1} \mathrm{yr}^{-1}$, corresponding to a soil erosion ranging between $1.24 \mathrm{~mm} \mathrm{yr}^{-1}$ and $0.97 \mathrm{~mm} \mathrm{yr}^{-1}$ ) were comparable to the erosion values estimated by data from the deposits: in fact the average basin mass removal of the two events was $12.3 \mathrm{Mg} \mathrm{ha}^{-1}$ (3.7 $\mathrm{Mg} \mathrm{ha}^{-1}$ and $20.8 \mathrm{Mg} \mathrm{ha}^{-1}$ ) with an estimated soil removal equal to $1.02 \mathrm{~mm}$. Moreover the estimates of erosion due to the avalanche activity were significantly greater than the erosion rates related only to runoff processes during the growing season. For example Konz et al. (2010) found values in the range of $0-68 \mathrm{~kg} \mathrm{ha}^{-1}$ month $^{-1}$, and also other studies confirmed low erosion rates during the vegetation period (e.g. Felix and Johannes, 1995; Simonato et al., 2002), even if the effective magnitude of this process depends strongly 


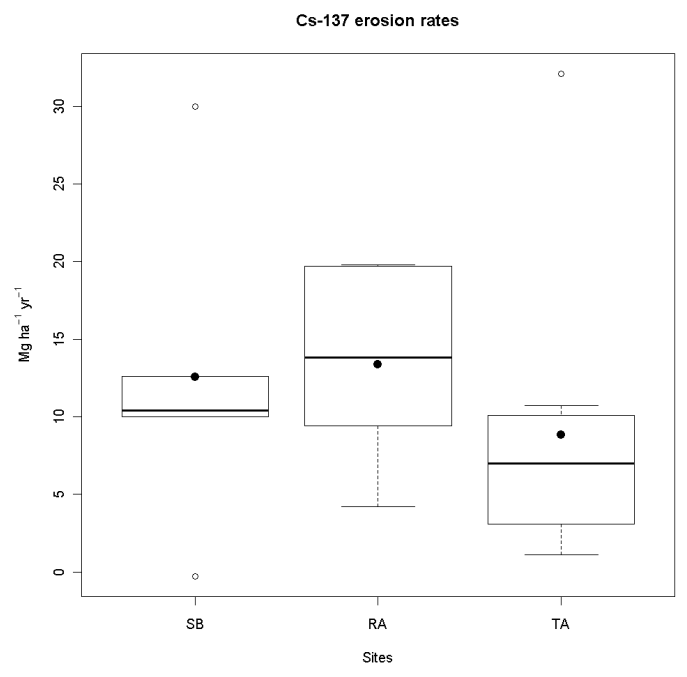

Fig. 9. Soil erosion rates found in the three sites: Snow Bridge area (SB); Release Area (RA); Track Area (TA) that includes the mean value of all the points belonging from $\mathrm{T} 1$ and $\mathrm{T} 2$. The dark full circles denote mean values, the blank dark circles represent outliers (i.e. more than 1.5 times the interquartile distance), and the black line is the median.

on the amount of the precipitation during the summer period (Felix and Johannes, 1995). Even though the comparison of both the approaches was linked to the high methodological uncertainties, mainly due to different spatial and temporal scales considered, we still could deduce, from the similarity of the erosion rates, that soil redistribution in this catchment is driven by snow movements.

\section{Conclusions}

Alpine regions are particularly susceptible to soil erosion because of their extreme climatic and topographic conditions. Avalanche paths are often places where soil is redistributed by snow movements (ground avalanches and snow gliding), as confirmed by the significant amount of sediments found in the deposits of the full-depth slab avalanche events considered in this study. The snow related soil accumulation estimated with data from the deposit area is not only higher than the yearly sediment amounts, reported in literature, due to runoff processes, but it is even more intense than the yearly total deposition rate assessed with ${ }^{137} \mathrm{Cs}$. This might be due to the disturbance of the lower deposition area by human activity and/or to the discrepancy between the long-term (since 1986) signal of the ${ }^{137} \mathrm{Cs}$ method compared to the rates of two single events (2009 and 2010). The snow related soil erosion rates estimated from the sediment yield at the avalanche deposit area are greater than the erosion rates reported in literature and related only to runoff processes. They are comparable to the yearly total erosion rates assessed with the ${ }^{137} \mathrm{Cs}$ method, and, even if the comparability between the two tech- niques is limited by their different time scale, both methods yielded similar magnitudes of soil redistribution rates.

The ${ }^{137} \mathrm{Cs}$ method also shows that, where ground avalanche doesn't release, the erosion and deposition of soil particles from the upper part of the basin is considerable and likely related to snow gliding, proving the very active contribution of the slow snow movements to the soil erosion. Even considering the large natural variability of event sediment loads and the temporal variability of avalanche occurrence, we may expect that, when a full-depth slab avalanche occurs, its contribution to the yearly soil erosion rate can be relevant, with values comparable to the total average yearly rates. In fact even hypothesizing that not every year a ground avalanche, with related soil erosion, could have occurred, the important role of avalanche processes in the soil redistribution rates is an undeniable fact. Consequently the soil erosion due to snow movements could be considered the main driving force of soil redistribution in this specific area, with a greater impact in comparison to the runoff processes occurring in the snow-free season. To which extend this is true for other areas less affected by ground avalanche release and snow gliding needs further investigation. Nonetheless, the study highlights that soil erosion processes due to the snow movement should be considered in the assessment of soil vulnerability in mountain areas as they significantly determine the pattern of soil redistribution.

Acknowledgements. This project is carried out as part of Operational programme "Italy-France (Alps-ALCOTRA)", Project "DynAval-Dynamique des avalanches: départ et interactions écoulement/obstacles". We would like to thank: Enrico Bruno and Alessandro Viarengo for their work in both field and laboratory activity; Gianluca Filippa, Silvia Stanchi and Margherita Maggioni for their suggestions and help; Paola Dellavedova and Simone Roveyaz for their support; J. Jourdan and D. Sacker (Department of Physics and Astronomy, University of Basel) for access to and help with the GeLi detector; Ruth Strunk and Heinz Huerlimann (University of Basel) for the laboratory analyses; Ufficio Centro Funzionale (Regione Autonoma Valle d'Aosta - Assessorato opere pubbliche, difesa del suolo e edilizia residenziale pubblica - Dipartimento difesa del suolo e risorse idriche), in particular Fabio Brunier, for the meteorological data; Claudio Operti (Agenzia Regionale per la Protezione dell' Ambiente - Valle d'Aosta) for the information about ${ }^{137} \mathrm{Cs}$ in the study area; Ufficio cartografico e sistemi informativi (Regione Autonoma Valle d'Aosta - Assessorato territorio e ambiente Dipartimento territorio e ambiente) for the cartographic support (1:10 000 maps, 2005, and orthophotos, 2006). Thanks also to the referees, Bernhard Kohl, Peter Molnar and Tobias Heckmann that really helped to improve this work. A special thank to all the friends met in Basel for their hospitality and friendship and to Renzino Cosson for his support in the fabulous "Bertone" mountain hut.

Edited by: M. Weiler 


\section{References}

Ackroyd, P.: Erosion by snow avalanche and implications for geomorphic stability, Torlesse Range, New Zealand, Arctic Alpine Res., 19, 65-70, 1987.

Agnesod, G., Operti, C., Zappa C., and Capodaglio, P.: Distribuzione comparata di Cs137 in diverse matrici ambientali sul territorio della Valle d'Aosta. ARPA (Agenzia Regionale per la Protezione dell'Ambiente), "Atti del III Convegno nazionale Controllo ambientale degli agenti fisici: dal monitoraggio alle azioni di risanamento e bonifica", Biella, 7-8-9 giugno, 2006.

Bell, L., Gardner, J., and DeScally, F.: An estimate of snow avalanche debris transport, Kaghan Valley, Himalaya, Pakistan, Arctic Alpine Res., 22, 317-321, 1990.

Bonnett, P. J. P.: A review of the erosional behavior of radionuclides in selected drainage basins, Journal of Environmental Radioactivity, 11, 251-266, 1990.

Boubakari, M. and Morgan, R. P. C.: Contour grass strips for soil erosion control on steep lands: a laboratory evaluation, Soil Use Manage, 15, 21-26, 1999.

Bozhinskiy, A. N. and Losev, K. S.: The fundamentals of avalanche science, Mitteilungen des Eidgenössisches Institute für Schneeund Lawinenforschung, 55, 280 pp., p. 227 (Translation of "Osnovy Lavinovedeniya", Leningrad, Gidrometeoizdat, 1987 by C. Bartelt), 1998.

Caine, N.: A model for alpine talus slope evolution by slush avalanching, J. Geol., 77, 92-100, 1969a.

Confortola, G., Maggioni, M., Freppaz, M., and Bocchiola, D.: Modelling soil removal from snow avalanches: a case study in the Italian Alps, Cold Regions Sci. Technol., 70, 43-52, 2011.

Descroix, L. and Mathys, N.: Processes, spatio-temporal factors and measurements of current erosion in the French Southern Alps: A review, Earth. Surf. Proc. Land., 28, 993-1011, 2003.

European Avalanche Warning Services: http://avalanches.org/, last access: 11 February 2012.

Facchinelli, A., Magnini, M., Gallini, L., and Bonifacio, E.: ${ }^{137} \mathrm{Cs}$ contamination from Chernobyl of soils in Piemonte (North-West Italy): spatial distribution and deposition model, Water Air Soil Pollut., 134, 341-352, 2002.

Felix, R. and Johannes, B.: Bodenerosionsuntersuchungen auf Testparzellen im Kalkhochgebirge, Mittlgn. Österreich, Geogr. Ges., 137, 76-92, 1995.

Freppaz, M., Lunardi, S., Maggioni, M., Valfrè, F., Bizzocchi, T., and Zanini, E.: Soil erosion caused by snow avalanches: preliminary results of two case studies in the Aosta Valley (NW-Italy), Poster Session, ISSW 2006, Telluride, Colorado, October 2006, 880-886, 2006.

Freppaz, M., Godone, D., Filippa, G., Maggioni, M., Lunardi, S., Williams, M. W., and Zanini, E.: Soil erosion caused by snow avalanches: a case study in the Aosta Valley (NW Italy), Arctic, AntArctic Alpine Res., 42, 412-421, 2010.

Gabriels, D., Ghekiere, G., Schiettecatte, W., and Rottiers, I.: Assessment of USLE cover-management C-factors for 40 crop rotation systems on arable farms in the Kemmelbeek watershed, Belgium. Soil Till. Res., 74, 47-53, 2003.

Gardner, J. S.: Observations on erosion by wet snow avalanches, Mount Rae area, Alberta, Canada, Arctic, AntArctic Alpine Res., 15, 271-274, 1983.

Heckmann, T., Wichmann, V., and Becht, M.: Quantifying sediment transport by avalanches in the Bavarian Alps - First results,
Zeitschriftfür Geomorphologie N.F., Suppl. 127, 137-152, 2002.

Higgitt, D. L., Froehlich, W., and Walling, D. E.: Applications and limitations of Chernobyl radiocaesium measurements in a Carpathian erosion investigation, Poland, Land Degradation \& Rehabilitation, 3, 15-26, 1992.

Isselin-Nondedeu, F. and Bedecarrats, A.: Influence of alpine plants growing on steep slopes on sediment trapping and transport by runoff, Catena, 71, 330-339, 2007.

Jomelli, V. and Bertran, P.: Wet snow avalanche deposits in the French Alps: structure and sedimentology, Geografiska Annaler, 83A(1/2), 15-28, 2001.

Kohl, B., Brauner, H., and Markart, G.: Soil erosion due to avalanches: measurements on an avalanche cone, International Symposium on Snowmelt and Related Problems, 28-30 March 2001, Oslo, Norway, 38, 2001.

Konz, N., Schaub, M., Prasuhn, V., Baenninger, D., and Alewell, C.: Caesium-137 based erosion-rate determination of a steep mountainous region, J. Plant Nutr. Soil Sci., 172, 615-622, 2009.

Konz, N., Baenninger, D., Konz, M., Nearing, M., and Alewell, C.: Process identification of soil erosion in steep mountain regions, Hydrol. Earth Syst. Sci., 14, 675-686, doi:10.5194/hess-14-6752010, 2010a.

Konz, N., Prasuhn, V., and Alewell, C.: On the measurement of Alpine Soil Erosion, Catena, 91, 63-71, 2010b.

Lana-Renault, N., Alvera, B., and García-Ruiz, J. M.: Runoff and Sediment Transport during the Snowmelt Period in a Mediterranean High-Mountain Catchment, Arctic, Antarctic Alpine Res., 43, 213-222, 2011.

Leitinger, G., Höller, P., Tasser, E., Walde, J., and Tappeiner, U.: Development and validation of a spatial snow-glide model, Ecol. Modell., 211, 363-374, 2007.

Leser, H., Meier-Zielinski, S., Prasuhn, V., and Seiberth, C.: Soil erosion in catchment areas of Northwestern Switzerland. Methodological conclusions from a 25 -year research programme, Z. Geomorphol., 46, 35-60, 2002.

Luckman, B. H.: The role of snow avalanches in the evolution of alpine talus slopes, Inst. Brit. Geogr., Spec. Pub., 3, 93-110, 1971.

Luckman, B. H.: The geomorphic activity of snow avalanches, Geografiska Annaler, 59A, 31-48, 1977.

Luckman, B. H.: Geomorphic work of snow avalanches in the Canadian Rocky Mountains, Arctic Alpine Res., 10, 261-276, 1978.

Mabit, L. and Fulajtar, E.: The use of ${ }^{137} \mathrm{Cs}$ to assess soil erosion and sedimentation processes: advantages and limitations, Book of the Extended Synopses of the International Conference on Environmental Radioactivity: From Measurements and Assessments to Regulation, IAEA Publication, 338-339, IAEA-cn-145, 2007.

Mabit, L., Benmansour, M., and Walling, D. E.: Comparative advantages and limitations of fallout radionuclides $\left({ }^{137} \mathrm{Cs}, 210 \mathrm{~Pb}\right.$ and $7 \mathrm{Be}$ ) to assess soil erosion and sedimentation, Journal of Environmental Radioactivity, 99, 1799-1807, 2008.

Meusburger, K., Konz, N., Schaub, M., and Alewell, C.: Soil erosion modelled with USLE and PESERA using QuickBird derived vegetation parameters in an alpine catchment, International Journal of Applied Earth Observation and Geoinformation, 12, 208215, 2010.

Nearing, M. A., Govers, G., and Norton, L. D.: Variability in soil 
erosion data from replicated plots, Soil Sci. Soc. Am. J., 63, 1829-1835, 1999.

Owens, P. N. and Walling, D.: Spatial Variability of Caesium-137 Inventories at reference Sites: an Example from Two Contrasting sites in England and Zimbabwe, Appl. Radiat. Isot., 47, 699-707, 1996.

Prasuhn, V., Liniger, H., Hurni, H., and Friedli, S.: Map of soil erosion risk in Switzerland, Agrarforschung, 14, 120-127, 2007.

Renaud, P., Pourcelot, L., Métivier, J.-M., and Morello, M.: Mapping of ${ }^{137} \mathrm{Cs}$ deposition over eastern France 16 years after the Chernobyl accident, Sci Total Environ., 309, 257-264, 2007.

Ritchie, J. C. and McHenry, J. R.: Application of radioactive fallout caesium-137 for measuring soil-erosion and sediment accumulation rates and patterns - a review, J. Environ. Qual., 19, 215-233, 1990.

Simonato, T., Bischetti, G. B., and Crosta, G. B.: Evaluating soil erosion with RUSLE and WEPP in an alpine environment (Dorena Valley - Central Alps, Italy), Sustain. Land Manage. Environ. Prot., 35, 481-494, 2002.

SMS: Atlante climatico della Valle d'Aosta. Società Meteorologica Subalpina, Torino, 239-241, 2003.
Sutherland, R. A.: Examination of Caesium-137 areal activities in control (uneroded) locations, Soil Technol., 4, 33-50, 1991.

Sutherland, R. A.: Caesium-137 soil sampling and inventory variability in reference locations: a literature survey, Hydrol. Process. J., 10, 43-53, 1996.

Walling, D. E. and He, Q.: Improved models for estimating soil erosion rates from caesium-137 measurements, J. Environ. Qual., 28, 611-622, 1999.

Walling, D. E. and Quine, T. A.: Calibration of caesium-137 measurements to provide quantitative erosion rate data, Land Degradation and Rehabilitation, 2, 161-175, 1990.

Wischmeier, W. H. and Smith, D. D.: Predicting Rainfall Erosion Losses: A Guide to Conservation Planning. Agriculture Handbook No. 537. USDA/Science and Education Administration, US. Govt. Printing Office, Washington, DC, 58, 1978.

Zapata, F. (Ed.): Handbook for the Assessment of Soil Erosion and Sedimentation using Environmental Radionuclides, Kluwer Ac. Publ., Dordrecht, The Netherlands, 219, 2002.

Zhang, X. B., Higgitt, D. L., and Walling, D. E.: A preliminary assessment of the potential for using caesium-137 to estimate rates of soil erosion in the Loess Plateau of China, Hydrol. Sci. J., 35, 267-276, 1990. 